\title{
Longitudinal movement of radioiodinated albumin within extravascular spaces of peripheral nerves following three systems of experimental trauma
}

\author{
ROSS MELLICK ${ }^{1}$ AND J. B. CAVANAGH \\ From the M.R.C. Research Group in Applied Neurobiology, Institute of Neurology, \\ Queen Square, London
}

Radioiodinated serum albumin leaks with ease into the endoneurial spaces of chicken nerves following experimental lesions (Mellick and Cavanagh, 1967a). The subsequent fate of this protein is, at the moment, ill understood, particularly since there are no lymphatics in the endoneurial space (Zupnik, 1905; Defrise, 1930).

This report is concerned with observations on the longitudinal movement of the leaked protein along the endoneurial spaces and is offered as an introduction to the larger problems of endoneurial flow and the functions of the perineurium that will be discussed more fully in another communication (Mellick and Cavanagh, 1967b).

\section{MATERIALS AND METHODS}

ANIMALS All experiments were performed on chickens of either Rhode Island Red crossed with Light Sussex or White Leghorn strains. They weighed between 750 and $1,500 \mathrm{~g}$. and were 8 to 12 weeks old. They were caged singly or in pairs and fed on Battery Layers Pellets ad libitum.

OPERATIVE PROCEDURES The sciatic nerves were either sectioned, crushed or tied.

The chickens were anaesthetized with ether. With aseptic precautions a longitudinal incision was made in the right thigh parallel to the femur and about half an inch posterior to it. The sciatic nerve was exposed by retraction of the overlying muscle belly with the minimum of disturbance to the nerve or to its bed. The site of tying and crushing chosen was midway between the point of exit of the nerve from the sciatic notch and the point of bifurcation in the region of the knee. The tie and crush were both performed with Ethicon black silk thread, $0.3 \mathrm{~mm}$. in diameter, and for the latter the thread was gently removed. The wound was then closed in

'Present address:-Department of Medicine, University of N.S.W., Sydney, Australia. layers with silk sutures and the skin incision covered with Collodion.

Nerve section was performed at a higher level, approximately 1 to $2 \mathrm{~cm}$. distal to the sciatic notch. The overlying muscle belly was split and the nerve sectioned with a sharp scalpel. The proximal part of the nerve between the point of sectioning and the sciatic notch was resected. The operation wound was closed as described previously.

The nerve on the left side was left undisturbed and used as the control.

REMOVAL OF SPECIMENS Blood was removed from a wing vein immediately, before the birds were killed, and was placed in a citrate bottle.

The birds were killed by an intracardiac injection of Nembutal; $2 \mathrm{ml}$. containing $60 \mathrm{mg}$. $/ \mathrm{ml}$. was usually used. The right sciatic nerve was then exposed from the sciatic notch to its bifurcation. A longitudinal stroke with a sharp scalpel blade was made immediately anterior and posterior to the nerve and it was divided at the sciatic notch, or if previously sectioned, gently dissected from its bed and removed. The nerve was blotted on absorbent paper and laid on a card with $6 \mathrm{~mm}$. distances measured on it. The nerve was then divided into eight $6 \mathrm{~mm}$. long segments if previously tied or crushed, or into three $12 \mathrm{~mm}$. long segments if previously sectioned. The segments were numbered respectively 1 to 8 or 1 to 3 in a distal direction.

The tie and crush were always between segments 4 and 5 . The specimens were placed in pre-weighed polythene bottles with tightly fitting caps.

WEIGHTS Dry weights were obtained by placing the opened containers into a drying oven at $80^{\circ} \mathrm{C}$. and dried to a constant weight.

RADIOISOTOPES USED AND METHOD OF ESTIMATING RADIOACTIVITY Iodinated ( $\left.{ }^{131} \mathrm{I}\right)$ albumin, sterile and pyrogen free, was obtained from the Radiochemical Centre, Amersham. Doses of between $50 \mu \mathrm{c}$. and $150 \mu \mathrm{c}$. were administered intravenously and estimations of radioactivity in the specimens of nerve performed after 
exposure to circulating isotope for one and for 24 hours. The entry of albumin into nerve during this time was used as an index of the blood vessel permeability. Radioiodinated albumin has been used previously by many workers to investigate blood vessel permeability (Cope and Moore, 1944; Wasserman and Mayerson, 1951; Boyse, Morgan, Pearson, and Wright 1956). There is evidence that heterologous albumin behaves in a similar manner to homologous albumin when administered to unsensitized animals (Dixon, Bukantz, and Dammin, 1951; Wasserman and Mayerson, 1952).

In this study the isotope content of the various specimens was determined first as counts $/ 100 \mathrm{sec} . / \mathrm{mg}$. dry wt., and then expressed as blood equivalents/mg. dry wt., in the manner of Boyse et al. (1956). This permitted the albumin content of nerves from birds with varying blood levels of radioactivity to be compared.

Radioiodine $\left({ }^{125} \mathrm{I}\right)$ was obtained from the Radiochemical Centre, Amersham, and it was attached to human albumin following the method of McFarlane (1958).

The blood content of the various specimens of nerve and skin was estimated using radioiodinated albumin, in a manner similar to that used by Aust, Chou, Marvin, Brackney, and Moore (1951). The isotopically labelled albumin was allowed to circulate for five minutes before the animal was killed, and the assumption was made that during this time the labelled albumin became evenly distributed throughout the total body vascular bed.

Gamma-radiation counting was performed on a Nuclear Enterprise scintillation counter with a differential pulse height analyser which permitted ${ }^{131}$ I albumin and ${ }^{125} \mathrm{I}$ albumin to be estimated in the same specimens. The polythene bottles fitted closely into the well of the shielded head unit (no. 5503). Appropriate corrections were applied for background activity, isotopic decay, and for breakthrough of ${ }^{131} \mathrm{I}$ radiation into the ${ }^{125} \mathrm{I}$ counts. Corrections for the blood content of the specimens were also applied so that the final results represent the extravascular albumin content expressed as blood Eq./mg. dry wt.
The extravascular radioiodinated albumin content of the various segments of nerve, however, did not necessarily represent albumin which had leaked from blood vessels in that segment. With exposure times of 24 hours there was ample time for albumin to leak at one site and for it to move within the endoneurial spaces to another site. With exposure times of one hour, however, the site of leaking blood vessels is accurately defined. Using exposure times of both one hour and 24 hours it was therefore possible to determine both the site of the leakage and the distribution of the leaked material after 24 hours.

STATISTICAL TESTS The statistical significance of the difference of the mean tracer content for various groups of animals was tested using student's t test.

\section{RESULTS}

SITE OF BLOOD VESSEL LEAKAGE DURING FIRST AND FOURTH DAYS AFTER NERVE SECTION, NERVE CRUSH, AND NERVE TIE All nerves were exposed to circulating radioiodinated albumin for a period of one hour.

Site of increased blood vessel permeability one day and four days after nerve section At the end of the first day following nerve section the extravascular albumin content of the segment of nerve immediately distal to the site of trauma increased to $0.26 \mathrm{Bl}$. Eq./ mg. after an exposure to circulating radioiodinated albumin for a period of one hour (Table I). This value is significantly greater than the control value of $0.06 \mathrm{Bl}$. Eq. $/ \mathrm{mg}$. $(\mathrm{P}<0.001)$. The extravascular albumin content of the two more distal segments was $0.08 \mathrm{Bl}$. Eq./mg. This did not represent a significant increase.

At the end of the fourth day following nerve section the extravascular albumin content rose to between 0.29 and $0.38 \mathrm{Bl}$. Eq. $/ \mathrm{mg}$. in all segments distal to the site of sectioning (Table I). Each of

TABLE I

EXTRAVASCULAR RADIOIODINATED ALBUMIN CONTENT OF CHICKEN SCIATIC NERVE AFTER SECTIONING, CRUSHING, AND TYING ${ }^{1}$

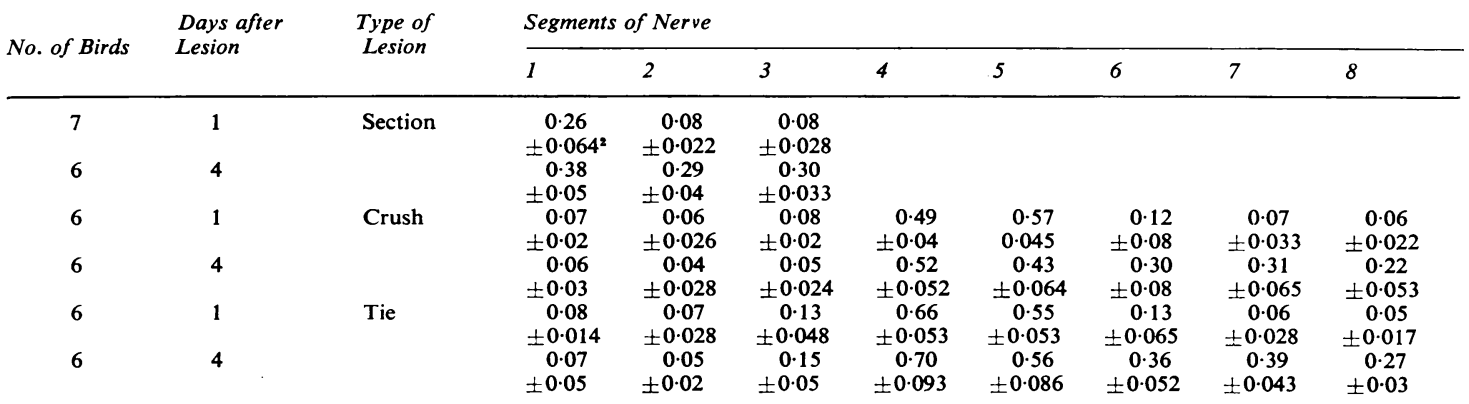

${ }^{1}$ The isotopically labelled protein was administered one hour before death.

${ }^{2}$ Mean $=$ Bl. Eq. $/ \mathrm{mg} . \pm$ S.D. 
these values is significantly greater than the control value $(\mathrm{P}<0.001)$.

During the first 24 hours following nerve section the site of blood vessel leakage is in the segment nearest the site of trauma. By the end of the fourth day after nerve section there is increased permeability of the blood vessels of all three segments of the isolated peripheral stump (Fig. 1).

Site of increased blood vessel permeability one day and four days after nerve crush At the end of the first day after the production of a crush lesion the extravascular albumin content of the segment immediately proximal (segment 4) and immediately distal (segment 5) to the site of the crush rose to 0.49 and $0.57 \mathrm{Bl}$. Eq. $/ \mathrm{mg}$. respectively (Table I). This elevation was highly significant $(\mathrm{P}<0 \cdot 001)$. The extravascular albumin content of the other segments proximal and distal to the site of the lesion varied between 0.06 and $0.12 \mathrm{~B} 1$. Eq. $/ \mathrm{mg}$. and represented no significant increase above the control value.

At the end of the fourth day, however, there was a highly significant increase in the extravascular albumin content of the one segment proximal to the site of the crush and of all the segments distal to it. The extravascular albumin content varied between 0.52 and $0.22 \mathrm{Bl}$. Eq. $/ \mathrm{mg}$. in these segments (Table I).

During the first 24 hours following the production of a crush lesion the site of blood vessel leakage is in the one $6 \mathrm{~mm}$. segment proximal and distal to the site of the lesion. By the end of the fourth day the segment immediately proximal to the site of the crush and all the $6 \mathrm{~mm}$. segments distal to the lesion exhibited increased permeability (Fig. 1).

Site of increased blood vessel permeability one day and four days after nerve ligature At the end of the first day following the application of a tie to a nerve there is an increase in the blood vessel permeability of the two segments immediately proximal and immediately distal to the tie. The extravascular radioiodinated albumin content of the segment immediately proximal to the tie (segment 4) is $0.66 \mathrm{Bl}$. Eq./mg., and of the segment immediately distal to the tie is $0.55 \mathrm{Bl}$. Eq./mg. The adjoining segments (segments 3 and 5) also exhibit a significantly increased albumin content, each containing $0 \cdot 13 \mathrm{Bl}$. Eq. $/ \mathrm{mg}$. (Table I). The other segments proximal and distal to the site of application of the tie contain between 0.05 and $0.08 \mathrm{Bl}$. Eq. $/ \mathrm{mg}$. These values do not represent a significant increase.

At the end of the fourth day after application of the tie there is a significant increase in the two segments immediately proximal to the tie and in all the segments distal to the tie, the extravascular albumin content varying between 0.70 and 0.15 Bl. Eq./mg. (Table I).

During the first 24 hours after application of a

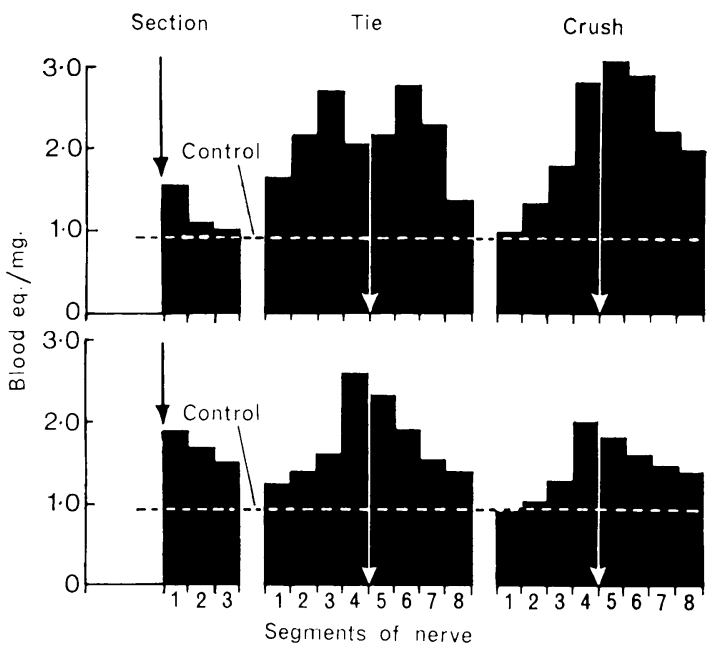

FIG. 1. Extravascular ${ }^{131}$ I albumin in chicken sciatic nerve following section, ligation and crush at one day (I) and four days (2).

Numbers refer to segments of nerve analysed serially in a distal direction. Arrows are points of section, tie, or crush.

tie the site of the blood vessel leakage is in the two segments proximal and distal to the tie. By the end of the fourth day, however, the two segments proximal to the site of the tie and all the segments distal to it exhibited increased blood vessel permeability (Fig. 1).

DISTRIBUTION OF EXTRAVASCULAR RADIOIODINATED ALBUMIN WITHIN THE PERIPHERAL NERVES 24 HOURS AND FOUR DAYS AFTER NERVE SECTION, NERVE CRUSH, AND NERVE TIE All nerves were exposed to circulating radioiodinated albumin for a period of 24 hours (Table II).

Distribution of extravascular radioiodinated albumin after nerve section During the first day after nerve section the extravascular albumin content of the $12 \mathrm{~mm}$. of nerve immediately distal to the site of sectioning (segment 1) increased to 1.59 Bl. Eq. $/ \mathrm{mg}$. This represents a rate of accumulation of 1.8 times the rate of accumulation in the normal nerves and is significantly greater than the rate of accumulation $(\mathbf{P}<0.001)$ in the controls and also in the two more distal segments (segments 2 and 3) of the sectioned nerve. The two more distal segments showed no increase above the normal value at this time.

Four days after the lesion was produced the extravascular albumin content rose to between 1.86 and $1.45 \mathrm{Bl}$. Eq. $/ \mathrm{mg}$. in all three segments. The increase was in each case significant $(P<0.001)$. 
TABLE II

EXTRAVASCULAR RADIOIODINATED ALBUMIN CONTENT OF CHICKEN SCIATIC NERVE AFTER SECTIONING, CRUSHING, AND TYING ${ }^{1}$

\begin{tabular}{|c|c|c|c|c|c|c|c|c|c|c|}
\hline \multirow[t]{2}{*}{ No of Birds } & \multirow{2}{*}{$\begin{array}{l}\text { Days after } \\
\text { Lesion }\end{array}$} & \multirow{2}{*}{$\begin{array}{l}\text { Type of } \\
\text { Lesion }\end{array}$} & \multicolumn{8}{|c|}{ Segments of Nerve } \\
\hline & & & 1 & 2 & 3 & 4 & 5 & 6 & 7 & 8 \\
\hline 6 & 1 & \multirow[t]{2}{*}{ Section } & 1.59 & 1.04 & 0.94 & & & & & \\
\hline 6 & 4 & & $\begin{array}{r} \pm 0.14 \\
1.86 \\
\pm 0.19\end{array}$ & $\begin{array}{r} \pm 0.16 \\
1.59 \\
\pm 0.15\end{array}$ & $\begin{array}{r} \pm 0.13 \\
1.45 \\
\pm 0.12\end{array}$ & & & & & \\
\hline 6 & 1 & \multirow[t]{4}{*}{ Crush } & 0.96 & $1 \cdot 30$ & 1.72 & 2.72 & 2.89 & 2.73 & 2.02 & 1.86 \\
\hline & & & $\pm 0 \cdot 19$ & $\pm \mathbf{0 . 3 8}$ & \pm 0.43 & $\pm \mathbf{0} \cdot 57$ & \pm 0.56 & \pm 0.54 & $\pm 0 \cdot 23$ & \pm 0.33 \\
\hline 5 & 4 & & 0.92 & 0.98 & 1.23 & 1.92 & 1.68 & 1.53 & 1.41 & 1.35 \\
\hline & & & \pm 0.22 & \pm 0.17 & \pm 0.30 & \pm 0.31 & \pm 0.24 & $\pm 0 \cdot 24$ & $\pm 0 \cdot 14$ & $\pm 0 \cdot 16$ \\
\hline 6 & 1 & \multirow[t]{3}{*}{ Tie } & $\begin{array}{r}1.60 \\
+0.24\end{array}$ & $\begin{array}{r}2.13 \\
+0.26\end{array}$ & $\begin{array}{r}2.58 \\
+0.14\end{array}$ & $\begin{array}{r}2.00 \\
+0.22\end{array}$ & $\begin{array}{r}2.09 \\
+0.14\end{array}$ & $\begin{array}{r}2.70 \\
+0.23\end{array}$ & $\begin{array}{r}2.26 \\
+0.49\end{array}$ & $\begin{array}{r}1.35 \\
+0.41\end{array}$ \\
\hline 5 & 4 & & $\begin{array}{r} \pm 0.24 \\
1.22\end{array}$ & $\begin{array}{r} \pm 0.26 \\
1.25\end{array}$ & $\begin{array}{r} \pm 0.14 \\
1.72\end{array}$ & $\begin{array}{r} \pm 0 \cdot 22 \\
2 \cdot 50\end{array}$ & $\begin{array}{r} \pm 0 \cdot 14 \\
2 \cdot 24\end{array}$ & $\begin{array}{r} \pm 0.23 \\
1.83\end{array}$ & $\begin{array}{r} \pm 0.49 \\
1.48\end{array}$ & $\begin{array}{r} \pm 0.41 \\
1.41\end{array}$ \\
\hline & & & \pm 0.15 & \pm 0.21 & \pm 0.25 & \pm 0.40 & \pm 0.34 & $\pm 0 \cdot 30$ & \pm 0.31 & $\pm 0 \cdot 16$ \\
\hline
\end{tabular}

${ }^{1}$ The isotopically labelled protein was administered 24 hours before death. Mean $=$ Bl. Eq. $/ \mathrm{mg} . \pm$ S.D.

Distribution of extravascular radioiodinated albumin after nerve crush During the first 24 hours after the production of a crush lesion there was a great increase in the extravascular albumin content of all the segments distal to the lesion and in the three segments immediately proximal to it $(P<0.05$, $>0.001$ ) (Table II). The albumin content increased to between 1.30 and $2.89 \mathrm{Bl}$. Eq. $/ \mathrm{mg}$. in these segments, representing rates of accumulation 1.5 to 3.2 times greater than in the controls. The albumin content fell off sharply in a proximal direction in contrast to the gradual decrease seen in the distal direction. The extravascular albumin content of segment 1 , the most proximally situated one, was $0.96 \mathrm{Bl}$. Eq. $/ \mathrm{mg}$. and not significantly different from the control value.

The mean content of albumin in the three most proximal segments (segments 1, 2, 3) was 1.3 Bl. Eq./ mg. and the three most distal segments (segments $6,7,8)$ was $2 \cdot 2 \mathrm{Bl}$. Eq./mg. The difference is highly significant $(P<0.001)$.

Four days after the crush was produced the extravascular albumin content rose significantly above the control values $(P<0.001)$ in the two segments immediately proximal to the lesion and in all the segments distal to it. These segments contained between 1.23 and $1.92 \mathrm{Bl}$. Eq./mg.

Distribution of extravascular radioiodinated albumin after nerve ligature Within the first 24 hours after the tie was applied there was a great increase in the extravascular albumin content of all segments, proximal and distal to the tie ( $P$ varied between $<0.05$ and $>0.001$ ) (Table II). The increase was most marked in the segments between $6 \mathrm{~mm}$. and $12 \mathrm{~mm}$. on either side of the tie. These segments contained $2 \cdot 58 \mathrm{Bl}$. Eq. $/ \mathrm{mg}$. and $2.70 \mathrm{Bl}$. Eq./ mg. respectively. The rate of accumulation of albumin in the two segments immediately proximal (segments 3 and 4), and the two segments immediately distal (segments 5 and 6), to the tie represent a rate of 3.1 and 2.7 times the rate of accumulation in the controls. There was a significant difference ( $P<0.001)$ between the content of segment 3 compared with segment 4 and of segment 5 compared with segment 6 . The trough in the histogram on either side of the tie is thus a real phenomenon. There is, however, no difference between the extravascular albumin contents of the one segment immediately proximal and distal to the tie at this time.

The mean content of albumin in the three most proximal segments (segments $1,2,3$ ) and in the most distal three segments (segments $6,7,8$ ) was $2 \cdot 1 \mathrm{Bl}$. Eq./mg.

Four days after the lesions were produced the extravascular albumin content rose to between 1.22 and $2.50 \mathrm{Bl}$. Eq./mg. in all segments. In each case the increase was significantly greater than the control value $(P<0.001)$.

\section{DISCUSSION}

The above experiments demonstrate that during the first $\mathbf{2 4}$ hours after the production of the three types of experimental lesion the site of increased blood vessel permeability is well localized to the region of the trauma. Four days after the lesions are produced, however, there is an increase in blood vessel permeability in all the segments distal to the site of the lesion. Because of this, the movement of the extravascular extracellular albumin in a distal direction can only be easily observed during the first $\mathbf{2 4}$ hours after the production of the lesions.

Following the crushing of the nerve there is marked asymmetry in the distribution of the leaked albumin along the nerve. Although the leakage is 
occurring almost equally in the segments immediately proximal (segment 4) and immediately distal (segment 5) to the lesion, and there is no evidence of increased permeability in the segments further proximally and further distally, the albumin is distributed mainly in a distal direction. Segments 6,7 , and 8 contain an average of $2 \cdot 2$ Bl. Eq. $/ \mathrm{mg}$. while segments 1,2 , and 3 contain an average of $1.3 \mathrm{Bl}$. Eq. $/ \mathrm{mg}$. dry weight. This represents a highly significant difference $(P<0.001)$. This is in marked contrast to the symmetrical distribution seen in the corresponding segments of the tied nerve $(2 \cdot 1 \mathrm{Bl}$. Eq./ mg. dry weight in each direction).

The histogram of the tied nerves shows a troughlike configuration in the region of the tie. There is a statistically significant difference between the albumin content of the segments immediately surrounding the tie and the segments once removed from the tie $(P<0.001)$. The site of maximum leakage, however, is in the segments immediately surrounding the tie. A possible reason for this is that the tie by converting the geometry of the nerve from something approaching a cylinder to something approaching a cone, thereby reduces the extracellular volume of the nerve and so diminishes the reservoir potentially available for occupation by the leaked albumin, causing it therefore to spread to adjacent segments where the distortion is less and where the extracellular space is not correspondingly diminished.

There appears to be no significant distal flow along the distal stump of the sectioned nerve. This observation is somewhat difficult to interpret because here, unlike the experimental circumstances in the tied and crushed nerves, the extracellular space of nerve is open and in free contact with the extracellular space of the surrounding tissue. No data were obtained on the amount of leakage into the surrounding tissue fluid from the open end.

There is much in the literature on the subject of the movement of foreign proteins such as viruses (Morgagni, 1769) and of tetanus toxin (Meyer and Ranson, 1903; Wright, 1953) along the peripheral nerves. This cited work was performed to investigate the role of the peripheral nerve as a route along which noxious agents could reach the central nervous system. It has at least been established that tetanus toxin (Friedemann Hollander, and Tarlov, 1941) can move from a distal site of injection into a muscle, along the endoneural spaces to the corresponding cord segment and produce localized tetanus. The case for the movement of virus particles in the same way, however, is not convincingly established. The toxin is thought to be propelled along the endoneural spaces by the forces of muscle contraction (Barcroft and Dornhorst, 1949; Drinker and Field, 1933; Wright, 1953). This would be in accord with the observation that toxin does not move along sensory nerves (Zupnik, 1905). However, movement of albumin observed in the above experiments cannot be explained by the forces generated by muscle contraction as the muscles are paralysed following the experimental lesion.

Weiss, Wang, Taylor, and Edds (1945) investigated the movement of potassium ferrocyanide and radioactive organic ions implanted or injected into the endoneural spaces of peripheral nerve. They concluded that there was a distal flow of endoneurial fluid. This was denied by Denny-Brown and Brenner (1944) who cited the persistence of a pseudo-neuroma at the site of the trauma as evidence against the distal flow of endoneural fluid.

The endoneural spaces do not have lymphatics (Defrise, 1930; Shdanow, 1931) and it might be expected that protein which has gained entry into these spaces in large amounts would be removed with difficulty and would accumulate there, in contrast to inorganic ions in water which could be readily absorbed by the vascular capillary system. Observations on the movement of potassium ferrocyanide, radioactive ions, and of water within the endoneurial spaces are thus not necessarily directly applicable to the movement of albumin within these spaces; indeed, water and protein $\frac{\mathrm{P}}{\mathrm{D}} \mathrm{O}$ distribute themselves differently following the three experimental lesions produced in the above experiments.

The physiological function of protein flow and the mechanism whereby it occurs may well be related 0 to the method for its removal from the endoneurial? spaces. The perineurium appears to be intimately concerned with maintaining the 'milieu interrieur' of the endoneurial fluid and its relation to, and influence on, protein flow and to fluid flow is the subject of a further communication (Mellick and Cavanagh, 1967b).

\section{SUMMARY}

After nerve section, nerve crush or ligature there is a vigorous increase in blood vessel permeability in the immediate vicinity of the trauma.

Serum albumin which leaks into the endoneurial space from the intraneural blood vessels in the immediate vicinity of the trauma spreads in a longitudinal direction along the nerve during the first 24 hours after the lesions are produced.

The spread occurs equally proximal and distal to the site of application of a tie but occurs predominantly in a distal direction following a crush lesion.

It is concluded that if an excessive amount of albumin gains entry to the extracellular spaces of 
nerves it moves predominantly in a distal direction if the endoneurial spaces are patent.

\section{REFERENCES}

Aust, J. B., Chou, S. N., Marvin, J. F., Brackney, E. L., and Moore, G. E. (1951). A rapid method for clinical total blood volume determination using radioactive iodinated human serum albumin (RIHSA). Proc. Soc. exp. Biol. (N.Y.), 77, 514-518.

Barcroft, H., and Dornhorst, A. C. (1949). The blood flow through the human calf during rhythmic exercise. J. Physiol. (Lond.), 109, 402-411.

Boyse, E. A., Morgan, R. S., Pearson, J. D., and Wright, G. P. (1956). The spread of a neurotropic strain of herpes virus in the cerebrospinal axis of rabbits. Brit. J. exp. Path., 37, 333-342.

Cope, O., and Moore, F. D. (1944). A study of capillary permeability in experimental burns and burn shock using radioactive dyes in blood and lymph. J. clin. Invest., 23, 241-257.

Dixon, F. J., Bukantz, S. C. and Dammin, G. J. (1951). The effect of sensitization and x-radiation on the metabolism of I-131 labeled proteins. Science, 113, 274-276.

Defrise, A. (1930). Ricerche anatomo-topografiche e microscopiche sui vasi linfatici dei nervi. Arch. gen. Neurol. Psichiat., 11, 102-118.

Denny-Brown, D. E., and Brenner, C. (1944). The effect of percussion of nerve. J. Neurol. Neurosurg. Psychiat., 7, 76-95.

Drinker, C. K., and Field, M. E. (1933). Lymphatics, Lymph and Tissue Fluid, p. 108. Baillière, Tindall and Cox, London.
Friedemann, U., Hollander, A., and Tarlov, I. M. (1941). Investigations on the pathogenesis of tetanus. J. Immunol., 40, 325-364.

McFarlane, A. S. (1958). Efficient trace-labelling of proteins with iodine. Nature (Lond.), 182, 53.

Mellick, R. S., and Cavanagh, J. B. (1967a). Changes in blood vessel permeability during degeneration and regeneration in peripheral nerves. Brain, in the press.

, and Cavanagh, J. B. (1967b). The functions of the perineurium. (In preparation).

Meyer, H., and Ransom, F. (1903). Untersuchungen über den Tetanus. Naunyn-Schmiedeberg's Arch. exp. Path. Pharmak. 49. 368-416.

Morgagni, J. B. (1769). The Seats and Causes of Diseases Investigated by Anatomy. English Translation, Vol. I, Letter VIII, para. 32. Millar and Cadell, London.

Shdanow, D. A. (1931) Die Lymphwege des peripherischen und Zentralnervensystems: I Die abführenden Lymphgefässe von Nervenstämmen der Extremitäten des Menschen. Anat. Anz., 71, 231-245.

Wasserman, K., and Mayerson, H. S. (1951). Exchange of albumin between plasma and lymph. Amer. J. Physiol., 165, 15-26.

- and Mayerson, H. S. (1952). Dynamics of lymph and plasma protein exchange. Cardiologia (Basel), 21, 296-307.

Weiss, P., Wang, H., Taylor, A. C., and Edds, V. (1945). Proximodistal fluid convection in the endoneurial spaces of peripheral nerves, demonstrated by colored and radioactive (isotope) tracers. Amer. J. Physiol., 143, 521-540.

Wright, G. Payling (1953). Nerve trunks as pathways in infection. Proc. roy. Soc. Med., 46, 319-330.

Zupnik, L. (1905). Die Pathogenese des Tetanus. Dtsch. med. Wschr., 31, 1999-2004.

\section{The August 1967 Issue \\ THE AUGUST 1967 ISSUE CONTAINS THE FOLLOWING PAPERS}

Effects of neonatal hypoglycaemia on the nervous system: a pathological study JOHN M. ANDERSON, R. D. G. MILNER, and SABINA J. STRICH

Peripheral neuropathy of metachromatic leucodystrophy: observations on segmental demyelination and remyelination and the intracellular distribution of sulphatide A. D. DAYAN

Independence of the galvanic skin reflex from the vasoconstrictor reflex in man B. J. PROUT

Excitability of spinal motor neurones in normal subjects and patients with spasticity, Parkinsonian rigidity, and cerebellar hypotonia P. ZANDER OLSEN and E. DIAMANTOPOULOS

An improved technique for radial nerve conduction studies ALLAN W. DOWNIE and THOMAS R. SCOTT

Laterality differences in the perception of pressure EILEEN FENNELL, PAUL SATZ, and ROBERT WISE

Granulomatous meningitis and diffuse parenchymatous degeneration of the nervous system due to an intracranial epidermoid cyst B. E. TOMLINSON and JOHN N. WALTON
Subacute necrotizing encephalopathy in an acidotic child PETER G. PROCOPIS, BRIAN TURNER, and GEORGE SELBY

Does pregnancy increase the risk of multiple sclerosis? URI LEIBOWITZ, AARON ANTONOVSKY, RACHEL KATS, and MILTON ALTER

Choreoathetosis in porto-systemic encephalopathy P. J. TOGHILL, A. W. JOHNSTON, and J. F. SMITH

Long-term effects of anterior temporal lobectomy on certain cognitive functions C. B. BLAKEMORE and MURRAY A. FALCONER

Depressive symptoms in Parkinson patients referred for thalamotomy J. W. WARBURTON

Metabolic balances of copper in patients with hepatolenticular degeneration submitted to vegetarian and mixed diets HORACIO M. CANELAS, FRANCISCO BASTOS DE JORGE, and WALDIR A. TOGNOLA

Plasma and erythrocyte magnesium in Huntington's chorea LAURA W. FLEMING, MONTAGU G. BARKER, and WILLIAM K. STEWART

Book reviews

Copies are still available and may be obtained from the PUBLISHING MANAGER, BRITISH MEDICAL ASSOCIATION, TAVISTOCK SQUARE, W.C.1., price, 18s. 6D. 